The Colonial Empires 


\section{The Colonial Empires}

A Comparative Survey from the Eighteenth Century

\section{K. Fieldhouse}

Vere Harmsworth Professor of Imperial and Naval History

Cambridge University 
CC 1965 by Fischer Bücherei KG, Frankfurt am Main and Hamburg, Germany

First English edition (c) 1966 published by Dell Publishing Co., Inc., New York and George Weidenfeld and Nicolson Ltd, London

Second edition 1982 published by THE MACMILLAN PRESS LTD

London and Basingstoke

Companies and representatives throughout the world

ISBN 978-0-333-33023-4 ISBN 978-1-349-06338-3 (eBook)

DOI 10.1007/978-1-349-06338-3

The paperback edition of this book is sold subject to the condition that it shall not, by way of trade or otherwise, be lent, resold, hired out, or otherwise circulated without the publisher's prior consent in any form of binding or cover other than that in which it is published and without a similar condition including this condition being imposed on the subsequent purchaser. 


\title{
Contents
}

Preface

xiii

\author{
PART ONE
}

THE COLONIAL EMPIRES BEFORE 1815

1 Introduction: The First Expansion of Europe 3

2 The Spanish and Portuguese Empires in America 11

The Spanish Empire in America

The Portuguese Empire in the Atlantic

3 The French and Dutch Empires in America

The French Empire

The Dutch Colonies in America

4 The British Empire, 1700-1815

The British Colonies in America before 1763

The British Empire, 1763-1815

5 Myths and Realities of the American Empires

6 The Disintegration of the American Empires

Imperial Redivision and Colonial Nationalism

The Revolt of the British Colonies, 1763-83

The End of the Spanish-American Empire

The Independence of Haiti

The Separation of Portugal and Brazil 


\section{CONTENTS}

7 Europeans in Africa Before 1815

8 Europeans in the East Before 1815

Portugal and Spain

Dutch, English and French Companies in the East

The Growth of Territorial Empires in the East

PART TWO

\section{THE COLONIAL EMPIRES AFTER 1815}

9 The Second Expansion of Europe, 1815-82

The Growth of European Power in Africa

European Expansion in Asia

European Expansion in the Pacific

10 Expansion, Partition and Redivision, 1883-1939

The Paper Partition, 1883-90

Partition and Effective Occupation, 1890-1914

Redivision and the Last European Expansion, 1914-39

11 The British Empire After 1815: I

Imperial Organization

The Settlement Colonies and Responsible Government, 1815-1914

Imperial Federation and the Growth of the Commonwealth

12 The British Empire After 1815: II

The Indian Empire, 1815-1947

The Dependent Empire after 1815

14 The Dutch, Russian and United States Colonial Empires

The Dutch Empire after 1815

The Russian Empire in Central Asia

The United States Empire 
CONTENTS

15 The Portuguese, Belgian and German Colonial

Empires

The Portuguese Empire after 1815

The Belgian Empire in the Congo

The German Colonial Empire

16 Myths and Realities of the Modern Colonial Empires 372

Contrasts Between the Old and Modern Empires

Similarities and Contrasts Between the Modern

Empires

The Myth of Economic Exploitation

17 Epilogue: Decolonization and After, 1945-81 395

Notes

411

Bibliography

417

Index 


\section{Maps}

Spanish and Portuguese colonial territories in Southern America c. 1790

The Caribbean in the 17th and 18th centuries 15

Colonial North America-1750 and 1763

Cook's search for a new continent 71

Africa as known to Europeans in the mid-18th century $\quad 128$

Eastern and Southern Asia c. $1775 \quad 158$

Russian advances in Central Asia 192

India 1753-1890 showing names of smaller districts and the sequence of territorial acquisition

The phases of French conquest of Indo-China 1858-93 199

Western expansion into South-East Asia $1914 \quad 219$

The pattern of alien rule in Africa 1914

Foreign holdings and spheres of influence in China c. $1900 \quad 230$

The South Pacific 1914

The Ottoman Empire 1914

South-West Asia: political divisions after World War I 237

The Colonial Empires 1914

Maps by Design Practitioners 


\section{Preface}

The character of the first edition of this book, published in German in 1965 and in English in 1966, was largely dictated by the fact that it was commissioned as one volume of an integrated series of histories, the Fischer Weltgeschichte. Other volumes were to deal with most countries which were at one time or another European colonies on a national or regional basis: for example, two volumes on Latin America, one each on the United States, India, South-east Asia, Africa, Modern Asia, and so on. My book had thus to fill a precise gap: to describe modern imperialism from the end of the seventeenth century, when the first colonial systems were well established, to 1945 when decolonization was about to begin; and to treat these empires as a specifically European phenomenon rather than as part of the history of particular non-European areas. I had, moreover, to do this very briefly.

I therefore decided to concentrate rather narrowly on three questions which seemed basic to all European colonial systems: why these were established; how they were run; and what advantages they provided. By the criteria of modern area studies this implied a one-sided approach because it largely ignored the indigenous history of the countries which became European colonies. Yet I believed, and still believe, that the process by which one country imposes and sustains control over another is a valid historical study and that the history of imperialism is distinct from that of particular imperial possessions. I also thought that European imperial history had a 


\section{PREFACE}

basic unity, so that to study one empire in isolation was likely to lead to distortion: hence the subtitle 'a comparative survey'.

The result was a highly condensed book in which I attempted to distil what seemed to me the essential features of modern European imperialism. Its value, as I thought, was that for the first time, so far as I know, it brought most of the imperial systems into a single focus, even though through a long-distance lens. Since 1965 imperial history has developed immensely and area studies have affected the way historians approach it. My original bibliography became badly out of date and my own ideas on some matters changed: for example, my interpretation of the 'new imperialism' of the period 1870-1914. Yet no other single book has yet covered quite the same subjectmatter; and, since I am happy to stand by almost all that I wrote originally, it has been decided to issue a second edition, making only four significant changes. Some minor inaccuracies in the text have been corrected. The illustrations, interesting but very expensive to reproduce, have been omitted. I have extended the last chapter on decolonization to take account of events between 1965 and 1981, making some tentative generalizations concerning the early effects of the end of empire on its one-time dependencies. Finally, I have revised and considerably extended the bibliography, cutting out books which are no longer the best in their field and adding a selection from the vast number published since 1965. I hope that in its new form the book may provide a first foothold for students as they start work on any aspect of modern imperial history.

DAVID FIELDHOUSE

Jesus College,

Cambridge 